Revista Eletrônica de Direito Processual - REDP. Volume 15. Janeiro a Junho de 2015

Periódico Semestral da Pós-Graduação Stricto Sensu em Direito Processual da UERJ.

Patrono: José Carlos Barbosa Moreira. www.redp.com.br ISSN 1982-7636 PP 416-434

\title{
O NOVO SISTEMA RECURSAL DO AGRAVO DE INSTRUMENTO CONTRA DECISÕES PROFERIDAS POR MAGISTRADOS DE PRIMEIRO GRAU ${ }^{1}$
}

\section{THE NEW SYSTEM OF GRIEVANCE'S RESOURCE OF INSTRUMENT AGAINST DECISIONS HANDED DOWN BY JUDGES OF FIRST DEGREE}

Ronaldo Pimenta Mendes Graduando em Direito pela Universidade José do Rosário Vellano.ronaldo8552@hotmail.com.

Deivison Resende Monteiro Mestre em Direito pela FDSM - Faculdade de Direito do Sul de Minas (Pouso Alegre MG). Graduado em Ciências Jurídicas pela Faculdade de Direito de Varginha (1999). Extensão universitária em Direito Eleitoral. Advogado regularmente inscrito na $\mathrm{OAB} / \mathrm{MG}$. Professor titular de Direito Internacional Público I e II, Direito Internacional Privado, Direito do Trabalho III e Direito Processual Civil V da Universidade José do Rosário Vellano UNIFENAS/CAMPO BELO. Consultor Jurídico no ramo do Direito Administrativo e Eleitoral. Consultor jurídico de Regimes Próprios de Previdência Municipal. Procurador do Instituto de Previdência Municipal de Boa Esperança de 2000 a 2004; Procurador Geral do Município de Boa Esperança de 2005 a 2012. Ocupante atualmente do cargo de Diretor Superintendente do Instituto de Previdência Municipal de Boa Esperança/MG.

\footnotetext{
${ }^{1}$ Revisor gramatical: Nicolas Vladimir de Souza Januario. Possui pós-graduação em Metodologia do Ensino Superior pelo Centro de Pesquisas Educacionais de Minas Gerais (CEPEMG) em parceria com Centro Universitário Newton Paiva (2008) e graduação em Letras - Português e Inglês e suas respectivas literaturas pelo Centro Universitário de Belo Horizonte (UNI-BH) (2003).
} 
Revista Eletrônica de Direito Processual - REDP. Volume 15. Janeiro a Junho de 2015 Periódico Semestral da Pós-Graduação Stricto Sensu em Direito Processual da UERJ. Patrono: José Carlos Barbosa Moreira. www.redp.com.br ISSN 1982-7636 PP 416-434

RESUMO: Almeja-se com o presente artigo demonstrar, de modo claro e conciso, as alterações advindas da Lei $\mathrm{n}^{\circ} 13.105 / 15$ no que tange ao recurso de agravo, mais especificadamente em relação às decisões dos magistrados de primeiro grau. Para tanto, contrasta-se as diretrizes imanentes do atual diploma, bem como os textos do Senado Federal e da Câmara dos Deputados. Ainda sob a ótica do novo Código de Processo Civil, passa-se a análise crítica da coerência sistemática entre o texto promulgado e o direito constitucional de defesa, além de construir ponderações acerca de possíveis problemas decorrentes do novo regime recursal.

PALAVRAS-CHAVE: Regime de agravo. Decisões interlocutórias. Novo CPC. Direito de defesa. Agravo de instrumento.

\begin{abstract}
Aims of the present article demonstrate, so clear and concise, the changes resulting from the Law $n^{\circ} 13.105 / 15$ in terms of the appeal of Grievance, more specifically in relation to the decisions of the judges in the first grade. For both, contrasts the immanent guidelines the current diploma, as well as the texts of the Federal Senate and Chamber of Deputies. Even from the perspective of the new Code of Civil Procedure, it is a critical analysis of systematic coherence between the text promulgated and the constitutional right of defense, in addition to building weights about possible problems arising from the new scheme recursal.
\end{abstract}

KEYWORDS: Scheme of tort. Interlocutory Decisions. New CPC. Right of defense. Tort of instrument

\title{
1) INTRODUÇÃO
}

Após os inúmeros debates ocorridos no Congresso Nacional, o novo Código de Processo Civil acaba de ser sancionado pela Presidência da República. Nesse sentido, a nova processualística civil, consubstanciada nos textos dos projetos de Lei ${ }^{\circ} 166 / 10$ (Senado Federal) e $n^{\circ}$ 8.046/10 (Câmara dos Deputados), acabou por desaguar, no dia 16 de março de 2015, na promulgação da Lei no 13.105. 
Revista Eletrônica de Direito Processual - REDP. Volume 15. Janeiro a Junho de 2015 Periódico Semestral da Pós-Graduação Stricto Sensu em Direito Processual da UERJ. Patrono: José Carlos Barbosa Moreira. www.redp.com.br ISSN 1982-7636 PP 416-434

Com várias alterações, muitas delas festejadas pela doutrina majoritária, o novo

Código de Processo Civil (NCPC) se inclina ao precípuo mister de desafogar o Judiciário. Neste ponto, imprescindível traçar com toda cautela que a boa razão nos fornece, a linha tênue que divide a celeridade, bem como a aparente segurança jurídica de um eventual cerceamento de defesa. Por vezes, os juristas mais desavisados confundem celeridade com eficiência. Atender as partes com o respeito que lhe é devido e, consequentemente, realizar o direito material é o verdadeiro fim do processo. ${ }^{2}$

Dos meios de resistência disponíveis pelas partes, os instrumentos recursais, indubitavelmente são dos mais importantes, vez que viabiliza dentro da mesma relação jurídica processual a reforma, anulação, integração ou aclaramento da decisão judicial impugnada. ${ }^{3}$ Neste sentido, cumpre evidenciar que o texto da Lei 13.105/2015, alterou substancialmente o regime do agravo contra decisões dos juízes de primeiro grau, fazendo-se mister pontuais esclarecimentos acerca destas modificações.

Conquanto almeje-se tratar do tema de modo satisfatório, deixe claro, entretanto, em razão da envergadura da questão, que não é objetivo deste artigo, esgotar a problemática do recurso de agravo de instrumento emanado do novo CPC. Assim, não se pretende uma análise aprofundada sobre todas as hipóteses em que cabível o agravo de instrumento e dos diversos dispositivos que regem a matéria sob a ótica do novo diploma processual.

Não se pode olvidar que o conteúdo que envolve a irrecorribilidade das decisões interlocutórias exige olhar amplo e, ao mesmo tempo profundo, vez que existem inúmeras hipóteses em que a nova sistemática processual significará agressão à ampla defesa. No entanto, este estudo está delimitado à temática que envolve, em especial, a questão da competência relativa e determinados entraves oriundos do ideal da taxatividade.

\section{2) DECISÃO INTERLOCUTÓRIA E O RECURSO DE AGRAVO SOB A ÉGIDE DA LEGISLAÇÃO ATUAL: CONCEITUAÇÕES E BREVES COMENTÁRIOS}

\footnotetext{
2 Por todos, cite-se, Barbosa Moreira quando afirma que "será efetivo o processo que constitua instrumento eficiente de realização do direito material". MOREIRA, José Carlos Barbosa. Por um processo socialmente efetivo. RePro 105/184. São Paulo: Ed. RT, 2002.

${ }^{3}$ NERY JUNIOR, Nelson; NERY, Rosa Maria de Andrade. Código de Processo Civil Comentado. Revista dos Tribunais, $13^{\circ}$ ed. São Paulo, 2013.
} 
Revista Eletrônica de Direito Processual - REDP. Volume 15. Janeiro a Junho de 2015 Periódico Semestral da Pós-Graduação Stricto Sensu em Direito Processual da UERJ. Patrono: José Carlos Barbosa Moreira. www.redp.com.br ISSN 1982-7636 PP 416-434

$\mathrm{O}$ recurso de agravo pode ser conceituado como meio de resistência conferido às partes, propício a combater decisões em distintas circunstâncias por meio de diversos instrumentos. Em consonância com a doutrina mais polida, o recurso de agravo deve ser encarado como gênero recursal, comportando ao menos cinco espécies:

"Contra as decisões interlocutórias de primeiro grau existem os agravos retido e de instrumento. Contra as decisões interlocutórias proferidas no Tribunal cabe agravo regimental; contra a decisão denegatória de seguimento de recurso especial e/ou recurso extraordinário, cabe o agravo previsto no art. 544 do CPC, e contra decisões monocráticas finais do relator existe o agravo interno. "4

Interessa-nos neste passo, o agravo contra decisões proferidas pelo juízo de primeira instância, sendo o recurso cabível contra as decisões interlocutórias em geral. ${ }^{5}$ Cumpre ressaltar que o momento da impugnação da decisão agravada será sempre de imediato. Conduto efetivar-se-á por atitudes distintas: uma de maneira retida, comportando apreciação posterior, condicionada que é ao recebimento da apelação, bem como a reiteração; outra de maneira instrumental, suportando exame imediato. ${ }^{6}$

Assim sendo, o agravo retido é o recurso hábil a permitir ao magistrado o reexame das decisões interlocutórias que proferiu em sede de primeira instância e, em caso de se manter inalterada a situação, o seu reexame pelo Tribunal competente quando do julgamento da apelação. Visa, portando afastar a ocorrência da preclusão para o agravante. $^{7}$

Hodiernamente, existem dois regimes jurídicos para o recurso de agravo retido: (i) contra decisão proferida em audiência, cuja interposição é oral ${ }^{8}$ e simultânea; (ii)

\footnotetext{
${ }^{4}$ NEVES, Daniel Amorim Assumpção. Manual de direito processual civil - 6. ed. rev., atual. eampl. Rio de Janeiro: Forense; São Paulo: Método, 2014, p.776.

${ }^{5}$ CÂMARA, Alexandre Freitas. Lições de direito processual civil. 23. ed. São Paulo: Atlas, 2014. v. 2.Pág.102.

${ }^{6}$ LESSA, Guilherme Thofehrn. Irrecorribilidade das decisões interlocutórias e regime de agravo de no projeto do novo CPC. Revista dos Tribunais Online. p.2. Disponível em: >http://goo.gl/fLODZU<. Acesso em: 09/01/2015.

${ }^{7}$ BUENO, Cassio Scarpinella. Curso sistematizado de direito processual civil, vol. 5: recursos, processos e incidentes nos tribunais, sucedâneos recursais: técnicas de controle das decisões jurisdicionais / - 5. ed. rev. e atual. - São Paulo: Saraiva, 2014, p. 172.

${ }^{8}$ Exigir o agravo retido na forma oral, ressalta o princípio da oralidade, que consiste no conjunto de sub princípios que interagem entre si, com o fito de fazer com que a prova seja colhida oralmente e julgada a
} 
Revista Eletrônica de Direito Processual - REDP. Volume 15. Janeiro a Junho de 2015

Periódico Semestral da Pós-Graduação Stricto Sensu em Direito Processual da UERJ.

Patrono: José Carlos Barbosa Moreira. www.redp.com.br ISSN 1982-7636 PP 416-434

aquele interposto contra decisão não proferida em audiência, revestindo-se de forma escrita e lapso temporal mais elástico, dez dias.

Neste sentido, cumpre ressaltar a doutrina da oralidade capitaneada por Chiovenda ${ }^{9}$, que contém como subprincípio a irrecorribilidade das interlocutórias, com vista a concentração do feito, vez que sob a ótica da audiência una, não haveria motivo para interrompê-la.

O agravo de instrumento, por sua vez, somente será o meio competente para resistir a um pronunciamento judicial decisório, quando se tratar de decisão suscetível de causar à parte lesão grave e de difícil reparação, além dos casos de inadmissão da apelação e nos relativos aos efeitos em que a apelação é recebida. ${ }^{10}$

Com efeito, conjugando-se os arts. 522 e 527, II, do atual CPC, afere-se que somente se a decisão agravada puder acarretar dano ao requerente, o agravo de instrumento pode ser invocado, caso contrário, será retido. ${ }^{11}$ Percebe-se que o critério não é cronológico, mas circunstancial, vinculado à aptidão da decisão interlocutória gerar danos. $^{12}$

O requisito de lesão grave ou de difícil reparação, exigido pelo atual regramento processual civil, é expressão larga e constitui conceito indeterminado ${ }^{13}$. Nesse sentido, faz-se relevante conhecer as peculiaridades do caso concreto, para o emprego adequado do agravo de instrumento. Indubitavelmente, o texto visa proteger o agravante de uma situação de eventual impossibilidade de regresso ao status quo ante.

Há ainda, hipóteses, em que a lei, por antecipação, impõe o agravo de instrumento, independentemente de existir ou não urgência ${ }^{14}$.São os casos de inadmissão da apelação e outros referentes aos efeitos em que a apelação é recebida ${ }^{15}$. Necessário não olvidar a existência de situações onde, a despeito da inexistência de

demanda pelo juiz que a colheu. Nesse sentido, NERY JUNIOR, Nelson; NERY, Rosa Maria de Andrade. Código de Processo Civil Comentado. Revista dos Tribunais, $13^{\circ}$ ed. São Paulo, 2013, p.478.

${ }^{9}$ Id, nota 5. LESSA (2014) apud CHIOVENDA (1938).

10 BRASIL. Lei $\mathrm{n}^{\mathrm{o}} 5.869$, de 11 de janeiro de 1973. Disponível em: $<$ http://www.planalto.gov.br/ccivil_03/leis/15869compilada.htm>. Acesso em: 10/01/2015.

${ }^{11}$ DIDIER JR., Fredie, CUNHA, Leonardo da Carneiro da. Curso de direito processual civil: meios de impugnação às decisões judiciais e processos nos tribunais. $11^{\circ}$ ed. Salvador: JusPodivm, 2013, v.3, p.162.

12 JORGE, Flávio Cheim. A nova reforma processual. $2^{\circ}$ ed. São Paulo: Saraiva, 2003, p. 174.

13 Nesse sentido, por todos: DIDIER JR., Fredie, CUNHA, Leonardo da Carneiro da. Curso de direito processual civil: meios de impugnação às decisões judiciais e processos nos tribunais. $11^{\circ}$ ed. Salvador: JusPodivm, 2013, v.3, p.163.

${ }^{14} \mathrm{Ib}$, nota 12 , p. 166.

${ }^{15}$ BUENO, Cassio Scarpinella. Curso sistematizado de direito processual civil, vol. 5: recursos, processos e incidentes nos tribunais, sucedâneos recursais: técnicas de controle das decisões jurisdicionais / - 5. ed. rev. e atual. - São Paulo: Saraiva, 2014, p. 181. 
Revista Eletrônica de Direito Processual - REDP. Volume 15. Janeiro a Junho de 2015 Periódico Semestral da Pós-Graduação Stricto Sensu em Direito Processual da UERJ. Patrono: José Carlos Barbosa Moreira. www.redp.com.br ISSN 1982-7636 PP 416-434 urgência, somente caberá agravo de instrumento em razão da incompatibilidade do agravo retido ${ }^{16}$.

Assim sendo, com espeque nas lições de Didier Jr. e Carneiro da Cunha, o agravante terá que se valer ou do agravo retido ou de instrumento, invocando-se o último em vez de o primeiro, quando a questão envolver risco de lesão grave ou de difícil reparação. ${ }^{17}$ Esclarecem os autores que não há que se falar em prevalência de um em relação ao outro ${ }^{18}$, vez que existem regras para o cabimento de agravo de instrumento e regras de agravo retido. ${ }^{19}$

Por meio da atual sistemática, permitindo a impugnação imediata da decisão questionada, consegue-se obstar a ocorrência da preclusão. Neste momento, cumpre invocar as lições esclarecedoras de Lessa, citando Moniz de Aragão, acerca das teorias que visam obstar a preclusão das interlocutórias:

"utiliza-se de uma das duas teses elaboradas pela doutrina para o controle das decisões interlocutórias, isto é, ou se tem a preclusão das questões decididas e não impugnadas, e deste modo se permite a impugnação imediata, com os autos retidos ou não, ou não ficam preclusas as questões decididas, podendo estas ser impugnadas somente com o recurso contra o julgamento final." ${ }^{20}$

\footnotetext{
${ }^{16}$ Cite-se o exemplo de Scarpinella Bueno: "a decisão que determina, como reforço, a penhora de um bem que o executado afirma ser bem de família; na atualização do valor da avaliação para fins de praceamento do bem em que se alega a utilização de indexador monetário em desarmonia com o da categoria do bem penhorado". Id nota 14, p.183.

${ }^{17}$ DIDIER JR., Fredie, CUNHA, Leonardo da Carneiro da. Curso de direito processual civil: meios de impugnação às decisões judiciais e processos nos tribunais. $11^{\circ}$ ed. Salvador: JusPodivm, 2013, v.3, p.154.

${ }^{18}$ Em sentido contrário, encontra-se o posicionamento do ilustre desembargador Alexandre Câmara: “ Deve-se dizer, porém e, preliminarmente, que como regra geral o agravo deve ser interposto na forma retida"CÂMARA, Alexandre Freitas. Lições de direito processual civil. 23º. ed. São Paulo: Atlas, 2014. v. 2.pág.102. No mesmo sentido, Scarpinella Bueno: "Desde a Lei n. 10.352/2001, a regra codificada passou a ser a de que o recurso de agravo deve ser interposto na sua modalidade retida, reservando-se o cabimento das demais modalidades para as hipóteses expressamente previstas pelo legislador. " BUENO, Cassio Scarpinella. Curso sistematizado de direito processual civil, vol. 5: recursos, processos e incidentes nos tribunais, sucedâneos recursais: técnicas de controle das decisões jurisdicionais / - 5. ed. rev. e atual. - São Paulo: Saraiva, 2014, p. 172.

${ }^{19} I d$. nota 5 .

${ }^{20} I d$.nota 5 .
} 
Revista Eletrônica de Direito Processual - REDP. Volume 15. Janeiro a Junho de 2015

Periódico Semestral da Pós-Graduação Stricto Sensu em Direito Processual da UERJ.

Patrono: José Carlos Barbosa Moreira. www.redp.com.br ISSN 1982-7636 PP 416-434

A conceituação de decisão interlocutória fica a cargo do atual Código de Processo Civil (Lei ${ }^{\circ}$ 5.869/1973), em seu art. 162, § 2. ${ }^{\circ}$, definindo como "o ato pelo qual o juiz, no curso do processo, resolve questão incidente".

Moniz de Aragão, com a clareza que lhe é peculiar, esclarece acerca dos requisitos essenciais da decisão interlocutória, derivadas do conceito legal, "primeiro requisito é que haja sido proferida no curso do processo, e o segundo é que resolva uma questão incidente" 21 .

Cumpre evidenciar crítica pontual da doutrina de Didier Jr., Braga e Oliveira, que entendem ser inoportuna a redação do art. 162, $\S 2^{\circ}$ do atual CPC, vez "procura definir esse tipo de decisão de acordo com o tipo de questão que ela resolve (questão incidente)", fazendo acreditar que a distinção da decisão interlocutória (primeiro grau) do instituto da sentença se dá pelo seu conteúdo. ${ }^{22}$

Questão é termo polissêmico, apresentando ao menos dois significados. Em um viés limitado, qualifica-se como qualquer ponto de fato ou direito controvertido de que dependa um pronunciamento judicial ${ }^{23}$.Em apertada síntese, são os pontos a serem examinados pelo magistrado. ${ }^{24}$

Entretanto, o vocábulo analisado, comporta ainda a interpretação de ser o "próprio thema decidendum, ou ao menos cada uma das partes em que ele se fraciona. "25 Por conseguinte, questão incidente é aquela, que necessariamente deve ser solucionada para que outra dita principal, possa ser efetivamente solucionada ${ }^{26}$. Nesse sentido, José Carlos Van Cleef de Almeida Santos afirma

"ser de essencial relevância que se perceba que a expressão tradicionalmente utilizada para qualificar os pronunciamentos

\footnotetext{
${ }^{21}$ ARAGÃo, Egas Dirceu Moniz de. Comentários ao Código de Processo Civil: Lei 5.869, de 11.01.1973: arts 154 a 269. 2. ed. Rio de Janeiro: Forense, 1976, vol. 02, p. 49.

${ }^{22}$ DIDIER JR., Fredie, BRAGA, Paula Sarno e OLIVEIRA, Rafael. Curso de direito processual civil: teoria da prova, direito probatório, teoria do precedente, decisão judicial, coisa julgada e antecipação dos efeitos da tutela. $8^{\circ}$. ed. Salvador: JusPodivm, 2013, vol. 2, p. 315.

${ }^{23}$ DIDIER JR., Fredie. Curso de direito processual civil: introdução do direito processual civil e ao processo de conhecimento. $15^{\circ}$ ed. Salvador:JusPodivm, 2013, vol. 1, p. 342.

24 "Os litigantes formulam no processo afirmações, que constituem 'pontos' a examinar. Se uma dessas afirmações (ponto) é contraditada pelo antagonista de quem a formulou, surge a questão, que é, portanto, o 'ponto controverso'. " ARAGÃO, Egas Moniz de. Sentença e coisa julgada. Rio de Janeiro: Aide,1992, p.254.

${ }^{25}$ MOREIRA, José Carlos Barbosa. Item do pedido sobre o qual não houve decisão. Possibilidade de reiteração noutro processo. Temas de direito processual civil - segunda série. $2^{\circ}$ ed. São Paulo: Saraiva, 1988, p.243.

${ }^{26} I d$, nota 21.
} 
Revista Eletrônica de Direito Processual - REDP. Volume 15. Janeiro a Junho de 2015

Periódico Semestral da Pós-Graduação Stricto Sensu em Direito Processual da UERJ. Patrono: José Carlos Barbosa Moreira. www.redp.com.br ISSN 1982-7636 PP 416-434

interlocutórios (interlocutiones, sentença interlocutória, despacho interlocutório e decisão interlocutória) ao longo dos anos questão incidente-, liga-se a uma ideia de contraposição do que seja questão principal e questão não principal (rectius: incidente, que é a questão desconexa com o mérito da causa). Não há vinculação entre decisão interlocutória e incidentes processuais propriamente ditos 27,

Portanto, o termo "questão incidente" utilizado com fins classificatórios da decisão interlocutória não trata, exclusivamente, da questão incidente ligada ao instituto do incidente processual propriamente dito, considerando versar de um comunicado necessário da sucessão de atos em contraditório, além de que frequentemente advém em qualquer processo judicial. Vê-se, que a decisão interlocutória não sana apenas uma questão acessória, de ocorrência anormal no desenrolar processual e desvencilhada do processo principal. ${ }^{28}$

Sendo assim, com espeque nas lições de Didier Jr., Braga e Oliveira, a decisão interlocutória é o comunicado por meio do qual o magistrado sana uma questão (incidente ou principal) sem esgotar a atividade jurisdicional ou qualquer de suas etapas, com relação a primeira instância. ${ }^{29}$

Assim, é possível perceber que o recurso de agravo de instrumento é o meio de resistência das decisões interlocutórias, quase que em sua totalidade, referente ao procedimento. Evidente, que a tutela do devido processo legal, com a consequente regularidade procedimental, logra-se pela possibilidade interposição do recurso de agravo de instrumento. ${ }^{30}$

\section{3) O SISTEMA DE AGRAVO DE INSTRUMENTO ALMEJADO PELA NOVA ORDEM PROCESSUAL CIVIL: EVOLUÇÃO OU RETROCESSO EM SEDE DE TUTELA DO DIREITO CONSTITUCIONAL DE DEFESA?}

\footnotetext{
27 SANTOS, José Carlos Van Cleef de Almeida.O projeto do novo código de processo civil e a (re) afirmação da decisão interlocutória de mérito. Revista dos Tribunais Online. p.14. Disponível em: http://goo.gl/DO4lHc. Acesso em: 10/01/2015, grifo do original.

${ }^{28} I d$, nota 26 .

${ }^{29} I d$, nota 21 .

${ }^{30}$ Coordenador: CARVALHO, Milton Paulo de. Conselho Superior de Direito da Fecomercio.Relatório da comissão de estudo e parecer sobre o projeto de código de processo civil.p.58. Disponível em:> http://s.conjur.com.br/dl/reforma-cpc-relatorio-conselho-superior.pdf $<$ Acesso em:10/01/2015.
} 
Revista Eletrônica de Direito Processual - REDP. Volume 15. Janeiro a Junho de 2015 Periódico Semestral da Pós-Graduação Stricto Sensu em Direito Processual da UERJ. Patrono: José Carlos Barbosa Moreira. www.redp.com.br ISSN 1982-7636 PP 416-434 COMPETENCIA RELATIVA E OUTROS PROBLEMAS ADVINDOS DO IDEAL DE TAXATIVIDADE

A Lei $\mathrm{n}^{\circ} 13.105 / 2015$ abraça um sistema preclusivo diverso do atual. Adota-se um regime de irrecorribilidade das interlocutórias, vez que estas decisões, pela regra geral, serão impugnadas em sede de apelação, eventualmente interposta contra decisões finais, ou nas contrarrazões. ${ }^{31}$

A partir dos directivos anteriores, salvo as hipóteses de agravo de instrumento, inexiste qualquer método de impugnação às interlocutórias sendo estas, irrecorríveis até o recurso contra a sentença. ${ }^{32}$ Com efeito, o texto do novo Código de Processo Civil prorroga o momento da interposição de recurso contra as interlocutórias, que na atual sistemática pode ser agravada de maneira retida, deixando de modificar o momento de apreciação do instrumento de resistência contra a decisão do magistrado. Não incidindo preclusão sobre a matéria, despiciendo um recurso com tal fim. Por esta razão, o mitigado instituto da preclusão sobre as interlocutórias foi extinto e, por consequência, o agravo retido. ${ }^{33}$

Outra relevante alteração, concerne a adoção do sistema taxativo de hipóteses que legitimam a interposição do agravo de instrumento. Mais uma vez fica claro o objeto do legislador em adotar o ideal da irrecorribilidade das interlocutórias. Contudo, nesse ponto, cumpre ressaltar a superioridade do texto da Câmara em relação ao do Senado. É que o texto do Senado limita demasiadamente as hipóteses de cabimento do recurso ora em comento. Entretanto, o texto da Lei ${ }^{\circ} 13.105 / 2015$, inclinou-se muito mais às disposições contidas no projeto apresentado pelo Senado Federal, infelizmente. Assim, apresenta-se o texto do art.969, bem como o do art. 1.028 e do art.1.015, referente ao Senado, a Câmara e ao texto promulgado, respectivamente, e cujos termos arrola-se:

O dispositivo arquitetado pelo Senado Federal assim dispunha:

Art. 969. Cabe agravo de instrumento contra as decisões interlocutórias que versarem sobre:

I - tutelas de urgência ou de evidência;

\footnotetext{
${ }^{31} I d$, nota 5 .

${ }^{32} \mathrm{Ib}$, nota 5 ; p. 3 .

${ }^{33} \mathrm{Ibdem}$, nota 31 .
} 
Revista Eletrônica de Direito Processual - REDP. Volume 15. Janeiro a Junho de 2015

Periódico Semestral da Pós-Graduação Stricto Sensu em Direito Processual da UERJ.

Patrono: José Carlos Barbosa Moreira. www.redp.com.br ISSN 1982-7636 PP 416-434

II - o mérito da causa;

III - rejeição da alegação de convenção de arbitragem;

IV - o incidente de resolução de desconsideração da

personalidade jurídica;

$\mathrm{V}$ - a gratuidade de justiça;

VI - a exibição ou posse de documentação ou coisa;

VII - exclusão de litisconsorte por ilegitimidade;

VIII - A limitação de litisconsórcio;

IX - a admissão ou inadmissão de intervenção de terceiros;

$\mathrm{X}$ - outros casos expressamente referidos em lei

Já a redação insculpida no projeto que tramitou na Câmara dos Deputados, trazia:

Art. 1.028. Além das hipóteses previstas em lei, cabe agravo de instrumento contra decisão interlocutória que:

I - conceder, negar, modificar ou revogar a tutela antecipada;

II - versar sobre o mérito da causa;

III - rejeitar a alegação de convenção de arbitragem;

IV - decidir o incidente de desconsideração da personalidade jurídica;

$\mathrm{V}$ - negar o pedido de gratuidade da justiçaou acolher o pedido de sua revogação;

VI - determinar a exibição ou posse de documento ou coisa;

VII - excluir litisconsorte;

VIII - indeferir o pedido de limitação do litisconsórcio;

IX - admitir ou não admitir a intervenção de terceiros;

$\mathrm{X}$ - versar sobre competência;

$\mathrm{XI}$ - determinar a abertura de procedimento de avaria grossa;

XII - indeferir a petição inicial da reconvenção ou a julgar

liminarmente improcedente;

XIII - redistribuir o ônus da prova nos termos do art. $380, \S 1^{\circ}$;

XIV - converter a ação individual em ação coletiva;

$\mathrm{XV}$ - alterar o valor da causa antes da sentença;

XVI - decidir o requerimento de distinção na hipótese do art. 1.050, 
Revista Eletrônica de Direito Processual - REDP. Volume 15. Janeiro a Junho de 2015

Periódico Semestral da Pós-Graduação Stricto Sensu em Direito Processual da UERJ.

Patrono: José Carlos Barbosa Moreira. www.redp.com.br ISSN 1982-7636 PP 416-434

$\S 13$, inciso I;

XVII - tenha sido proferida na fase de liquidação ou de cumprimento de sentença e nos processos de execução e de inventário;

XVIII - resolver o requerimento previsto no art. 990, $\S 4^{\circ}$;

XIX - indeferir prova pericial;

XX - não homologar ou recusar aplicação a negócio processual celebrado pelas partes.

Todavia, a redação final do dispositivo que trata do agravo de instrumento e que compôs o texto da Lei 13.105/2015, assim dispõe:

Art. 1.015. Cabe agravo de instrumento contra as decisões interlocutórias que versarem sobre:

I - tutelas provisórias;

II - mérito do processo;

III - rejeição da alegação de convenção de arbitragem;

IV - incidente de desconsideração da personalidade jurídica;

V - rejeição do pedido de gratuidade da justiça ou acolhimento do pedido de sua revogação;

VI - exibição ou posse de documento ou coisa;

VII - exclusão de litisconsorte;

VIII - rejeição do pedido de limitação do litisconsórcio;

IX - admissão ou inadmissão de intervenção de terceiros;

X - concessão, modificação ou revogação do efeito suspensivo aos embargos à execução;

XI - redistribuição do ônus da prova nos termos do art. 373, § 1丷ㅜㅇ

XII - (VETADO);

XIII - outros casos expressamente referidos em lei.

Parágrafo único. Também caberá agravo de instrumento contra decisões interlocutórias proferidas na fase de liquidação de sentença ou de cumprimento de sentença, no processo de execução e no processo de inventário.

Neste diapasão, vale a análise com a devida cautela sugerida na introdução deste ensaio. É de clareza solar que o Poder Judiciário encontra-se abarrotado de processos, 
Revista Eletrônica de Direito Processual - REDP. Volume 15. Janeiro a Junho de 2015 Periódico Semestral da Pós-Graduação Stricto Sensu em Direito Processual da UERJ. Patrono: José Carlos Barbosa Moreira. www.redp.com.br ISSN 1982-7636 PP 416-434 além dos inúmeros agravos interpostos que ensejaram várias reformas processuais, e que o diálogo entre os seres sociais se encontra cada vez mais fragmentado ${ }^{34}$, vez que o outro é encarado como estranho ${ }^{35}$.

Entretanto, mesmo diante dessa realidade questionável é a opção do legislador em restringir as hipóteses de cabimento do recurso de agravo de instrumento, que poderá importar, consequentemente, em sacrifício do direito de defesa comportando sua face maior, a do acesso à justiça (art. $\left.5^{\circ} \mathrm{XXXV}\right)$.

A comissão de estudo e parecer sobre o projeto do novo código de processo civil, assim já se posicionou, afirmando quedar "manietado e amordaçado por decisões irrecorríveis que venham a desviar o curso regular do processo, e o litigante estará privado do último remédio que lhe oferece o Estado de Direito, o ingresso na Justiça"36.

Mais fácil embaraçar a efetivação do devido processo legal do que investir no judiciário? A situação com toda certeza será mais trabalhada pela doutrina. Contudo, desde já, é possível se afirmar que não. Sobre o tema, Grezelle assevera:

A proposta não se sustenta, e chega a ser preocupante. Elenca o projeto um rol taxativo, numerus clausus, de nove hipóteses de cabimento de agravo de instrumento, mais casos expressamente previstos em lei. Nesse rol constam as espécies de decisões responsáveis pela esmagadora maioria de recursos, máxime a tutela de urgência, o que enfraquece por demais o desiderato da já controvertida modificação. Ficando de fora das hipóteses de cabimento apenas decisões que não possuem força estatística para justificar o objetivo de celeridade, de nada serve/ a modificação senão para criar injustiças e anomalias. $^{37}$

\footnotetext{
${ }^{34}$ BAUMAN, Zygmunt. Modernidade líquida. Trad. Plínio Dentzien. Rio de Janeiro: Jorge Zahar, 1999. p. 46.

${ }^{35}$ BAUMAN, Zygmunt. Identidade. Trad. Plínio Dentzien. Rio de Janeiro: Jorge Zahar, 2005. p. 35.

${ }^{36} I d$, nota 29.

${ }^{37}$ GREZELLE, Vinicius. Comentários ao Projeto de Lei $n^{0} .8 .046 / 2010$, Proposta de um Novo Código de Processo Civil. Porto Alegre: EdiPUCRS, 2012. p. 561, grifo no original.
} 
Ainda sobre o tema, cite-se o pensamento de Costa Machado:

Outro lado claro da insensibilidade do projeto de CPC é a apelação por instrumento que vai dificultar o exercício do direito de recorrer e, com ele, o exercício do próprio direito de defesa. Imagine-se o tamanho do problema com que terão de lidar muitos milhares de advogados do Brasil para reproduzir centenas de peças dos autos, de sorte a poder enviá-las ao tribunal junto com seu recurso. ${ }^{38}$

Assim sendo, lamentável que a Lei 13.105/15 imponha limitação ao agravo de instrumento sob a afirmação de o mesmo ser o grande problema dos tribunais, expondo as partes a eventuais ilegalidades cometidas pelo juízo de primeira instância. Atar a possibilidade de recurso somente ao final do processo, realmente instigará os tribunais de segundo grau a fazer "vistas grossas" para possíveis irregularidades, nulidades ou demais vícios ocorridos no desenrolar processual.

Com efeito, a problemática colará os tribunais frente a uma peculiar questão: ao acolherem a preliminar de contestação ou contrarrazões, o princípio da economia processual se esvai; ao deixar passar como despercebido algum vício e não acolherem a preliminar com fito de proteção à economia, a injustiça se estabelece, porque tornarão, na prática, a decisão interlocutória irrecorrível. ${ }^{39}$

A limitação das hipóteses de cabimento do agravo de instrumento revela situação complexa, tanto pelo viés de impingir mais dificuldade na resistência das partes em relação ao decisium do magistrado de primeiro grau, quanto pelo eventual recurso de apelação totalmente inócuo. Aqui, as ponderações se direcionam mais especificadamente às hipóteses de ajuizamento do agravo de instrumento na nova ordem processual civil.

Como visto, o texto da Lei $\mathrm{n}^{\circ} 13.105 / 2015$ não comporta o agravo de instrumento em situações imanentes de decisões acerca de competência. Assim, a

\footnotetext{
${ }^{38}$ MACHADO, Antônio Cláudio da Costa. Reforma do CPC é vontade de criar totalitarismo judicial. Disponível em:> http://www.conjur.com.br/2013-mar-22/costa-machado-reforma-cpc-vontade-criartotalitarismo-judicial $<$. Acesso em: 10/01/2015.

39 Todo o raciocínio acima exposto é desenvolvido pelo brilhante professor Daniel Amorim em sua obra de processo civil. NEVES, Daniel Amorim Assumpção. Manual de direito processual civil - 6. ed. rev., atual. eampl. - Rio de Janeiro: Forense; São Paulo: Método, 2014, p.780-782.
} 
Revista Eletrônica de Direito Processual - REDP. Volume 15. Janeiro a Junho de 2015

Periódico Semestral da Pós-Graduação Stricto Sensu em Direito Processual da UERJ.

Patrono: José Carlos Barbosa Moreira. www.redp.com.br ISSN 1982-7636 PP 416-434

competência relativa como regra criada para atender interesses privados é passível de prorrogação $^{40}$. De conseguinte, a aplicação do princípio do pas de nullitésansgrief ${ }^{41}$ afirma que não se decreta nulidade sem prejuízo. Além da instrumentalidade das formas prescrever que caso o ato, ainda que realizado de outro modo, alcance sua finalidade, a validade do mesmo deve ser considerada pelo magistrado.

Feitas essas ponderações, uma questão surge: como se resolveria a situação onde um magistrado indefere a exceção de incompetência relativa (portando-se, deste modo, como competente), decide a lide em todos os seus termos e, consequentemente põe fim ao processo?

Ora, deverá o interessado em sede de apelação arguir a incompetência relativa do juízo, por óbvio. Nesta senda, o tribunal irá invalidar todos os procedimentos adotados e "jogar no lixo" dinheiro e tempo das partes e do judiciário e, consequentemente, decretar nula a decisão? Aqui, outras dúvidas se apresentam:

O regime atual, no que tange a incompetência relativa, entende que os atos decisórios são aproveitados. Então como se resolveria a questão acima narrada? Ademais, decorrido lapso temporal tão grande já não se teria prorrogado tal competência? Lembre-se que a nulidade de algibeira ${ }^{42}$ é rejeitada pelo Superior Tribunal de Justiça e o novo texto silencia-se quanto a atitude a ser adotada em caso de indeferimento de exceção de incompetência relativa. Seria necessário a parte manifestar a discordância por simples petição com viso de obstar a prorrogação da competência, vez que, deixando para se manifestar no futuro, poder-se-á configurar hipótese de nulidade de algibeira?

O mesmo se diga acerca da rejeição da alegação de convenção de arbitragem. O que advém, caso ocorra eventual acolhimento indevido da convenção de arbitragem? Mais dinheiro e tempo desperdiçados! Acresce-se a pontual ponderação de Marinoni e

\footnotetext{
${ }^{40}$ DIDIER JR., Fredie. Curso de direito processual civil: introdução do direito processual civil e ao processo de conhecimento. $15^{\circ}$ ed. Salvador: JusPodivm, 2013, vol. 1, p. 149-151.

${ }^{41}$ Para mais aprofundamentos conferir: DIDIER JR., Fredie. Curso de direito processual civil: introdução do direito processual civil e ao processo de conhecimento. $15^{\circ}$ ed. Salvador: JusPodivm, 2013, vol. 1.

${ }^{42}$ STJ - Terceira Turma rejeita estratégia de "nulidade de algibeira" utilizada pela parte. A Terceira Turma do Superior Tribunal de Justiça (STJ) rejeitou uma arguição de nulidade, pois entendeu que a estratégia utilizada pela parte configurava, na realidade, uma manobra - a chamada "nulidade de algibeira", expressão cunhada pelo falecido ministro Humberto Gomes de Barros no julgamento do Recurso Especial (REsp) 756.885. De acordo com o colegiado, a "nulidade de algibeira" ocorre quando a parte permanece em silêncio no momento oportuno para se manifestar, deixando para suscitar a nulidade em ocasião posterior. REsp 1372802-RJ. Disponível em: $>$ http://www.tjsp.jus.br/Download/SecaoDireitoPrivado/Boletins/GapriInformaAbril2014.pdf $<. \quad$ Acesso em: 10/01/2015.
} 
Revista Eletrônica de Direito Processual - REDP. Volume 15. Janeiro a Junho de 2015 Periódico Semestral da Pós-Graduação Stricto Sensu em Direito Processual da UERJ. Patrono: José Carlos Barbosa Moreira. www.redp.com.br ISSN 1982-7636 PP 416-434

Mitidiero em relação ao risco de privar a arbitragem de uma das suas características mais relevantes, qual seja, a tempestividade ${ }^{43}$.

Essa diretriz do Projeto, contudo, fragiliza em demasiado o sistema de arbitragem brasileiro. Em outras palavras: outorga proteção insuficiente à autonomia da vontade e à liberdade contratual que sustentam a arbitragem brasileira. Ao condicionar a revisão da decisão interlocutória de primeiro grau ao advento do julgamento da apelação, corre-se o risco e despojar o instituto da arbitragem de uma de suas principais características: a tempestividade da tutela arbitral. É conveniente rever essa posição. $^{44}$

Estes são alguns dos vários questionamentos possíveis acerca desta nova sistemática do recurso de agravo de instrumento adotada pelo texto da Lei $\mathrm{n}^{\circ}$ $13.105 / 2015$.

No que concerne à forma e ao procedimento do agravo de instrumento, destacam-se duas inovações: O novo Código Processual Civil que esclarece acerca da possibilidade de substituição da certidão de intimação da parte por outro documento oficial hábil a comprovar a tempestividade do recurso de agravo para a formação do instrumento (art.1017, I, da Lei $\mathrm{n}^{\circ}$ 13.105/2015). Havendo facultatividade acerca da juntada, os autos do processo em primeiro grau de jurisdição, de cópia da petição de agravo, sua ausência não mais importaria em inadmissibilidade do recurso, como bem esclarecem Marinoni e Mitidiero, apenas restaria inviabilizado o exercício facultativo de retratação judicial ${ }^{45}$ (art.1.031, do projeto de lei $n^{\circ}$ 8.046/2010).

Contudo, no texto do novo Código de Processo Civil, afere-se disposição no sentido de desnecessidade de juntada de cópia da petição de agravo aos autos do processo em primeiro grau de jurisdição, apenas na hipótese do processo ser eletrônico, por sinal, uma disposição óbvia. Caso contrário, terá o agravante prazo de três dias, a contar da interposição do agravo, para a requerer a juntada de cópia da petição do

\footnotetext{
${ }^{43}$ MARINONI, Luiz Guilherme. MITIDIERO, Daniel. O projeto do CPC: críticas e propostas. $1^{\circ} \mathrm{ed}, 2^{\circ}$ tiragem. São Paulo, Editora Revista dos Tribunais, 2010, p, 182-183.

${ }^{44} I d$, Ibdem, p, 182, grifo no original.

${ }^{45} I d$, nota 42 .
} 
Revista Eletrônica de Direito Processual - REDP. Volume 15. Janeiro a Junho de 2015 Periódico Semestral da Pós-Graduação Stricto Sensu em Direito Processual da UERJ. Patrono: José Carlos Barbosa Moreira. www.redp.com.br ISSN 1982-7636 PP 416-434

agravo de instrumento aos autos do processo, sob pena de inadmissibilidade do mesmo, na hipótese de o agravado arguir e provar que o agravante descumpriu tal imposição (art.1.018, caput, $\S 2^{\circ}, \S 3^{\circ}$ da Lei 13.105/2015).

\section{4) CONCLUSÃo}

A sociedade evolui e o direito tende a acompanhar esse desenvolvimento. É inegável que a Lei 13.105/2015 que cria um novo texto do Código de Processo Civil, nos brinda com várias alterações pertinentes. É da natureza humana ter receio do desconhecido. Entretanto, não menos natural é debater pontos controvertidos acerca das resoluções de problemas.

O grande mestre Buzaid, na exposição de motivos do atual Código de Processo Civil já se manifestava no sentido que de a ordem revogada não é de todo inútil, muito pelo contrário, vez que se pode aproveitar os materiais do prédio demolido para sua utilização em construções futuras.

Entra em jogo dois princípios antagônicos de técnica legislativa: o da conservação e o da inovação. Ambos se harmonizam, porque, se o primeiro torna menos perturbadora a mudança, o segundo remedeia os males observados durante a aplicação do Código. O reformador não deve olvidar que, por mais velho que seja um edifício, sempre se obtêm, quando demolido, materiais para construções futuras. ${ }^{46}$

A época das soluções imediatas, exara em seu valor maior, a velocidade ${ }^{47}$, também a sua peculiar fragilidade. Mascara-se a realidade, imuniza-se o sistema político contra outras possibilidades e, consequentemente, a ideologia domina os campos de produção de conhecimento. O legislativo já se mostra claramente corrompido com essa situação. A era da legislação simbólica vige em nossa sociedade ${ }^{48}$. Portanto, o judiciário

\footnotetext{
${ }^{46}$ BUZAID, Alfredo. Exposição de motivos do código de processo civil. In Código de Processo Civil, HISTÓRICO DA LEI Vol. I TOMO I. Disponível em:>http://www2.senado.leg.br/bdsf/bitstream/handle/id/177828/CodProcCivil\%201974.pdf?sequence=4 $<$ Acesso em: 10/01/2015, p.11.

${ }^{47}$ MARCUSE, Herbert. Ideologia da sociedade industrial. 3. ed. Rio de Janeiro: Jorge Zahar, 1969.

${ }^{48}$ Marcelo Neves afirma que: "a legislação simbólica aponta para o predomínio, ou mesmo hipertrofia, no que se refere ao sistema jurídico, da função simbólica da atividade legiferante e seu produto, a lei,
} 
Revista Eletrônica de Direito Processual - REDP. Volume 15. Janeiro a Junho de 2015 Periódico Semestral da Pós-Graduação Stricto Sensu em Direito Processual da UERJ. Patrono: José Carlos Barbosa Moreira. www.redp.com.br ISSN 1982-7636 PP 416-434

deverá, mais do que nunca, se portar de maneira cautelosa quando da aplicação legal de institutos obscuros, que muitas das vezes visam apenas demonstrar a prevalência dos interesses dos grupos dominantes na ânsia de sua glorificação, com a consequente degradação do grupo opositor. ${ }^{49}$

A famosa morosidade do judiciário chega a legitimar a possibilidade de julgamentos receosos em relação às decisões impugnadas. Afinal, sacrificar a celeridade por meio da reforma que objetiva sua concretização é no mínimo paradoxal! Com efeito, não se deve olvidara possiblidade do uso abusivo dos mandados de segurança que, muito provavelmente, serão impetrados, com vistas a obter a suspensão do processo e o julgamento imediato de hipóteses não contempladas em lei ${ }^{50}$.

Enfim, como já afirmado, celeridade e eficiência, são conceitos que não se confundem. Um processo civil que suprime importantes instrumentos de resistência com fins virtuais de obtenção de celeridade, em detrimento da realização do direito material é um processo civil dominado por voláteis ideologias. Circunstâncias que jamais poderiam ocorrer em uma processualística com fins de justiça.

\section{REFERÊNCIAS BIBLIOGRÁFICAS}

ARAGÃO, Egas Dirceu Moniz de. Comentários ao Código de Processo Civil: Lei 5.869, de 11.01.1973: arts 154 a 269. 2. ed. Rio de Janeiro: Forense, 1976, vol. 02. ARAGÃO, Egas Moniz de. Sentença e coisa julgada. Rio de Janeiro: Aide,1992. BAUMAN, Zygmunt. Modernidade líquida. Trad. Plínio Dentzien. Rio de Janeiro: Jorge Zahar, 1999.

BAUMAN, Zygmunt. Identidade. Trad. Plínio Dentzien. Rio de Janeiro: Jorge Zahar, 2005.

sobretudo em detrimento da função jurídico-instrumental. " NEVES, Marcelo. A constitucionalização simbólica. São Paulo: WMF Martins Fontes, 2007, p.23.

${ }^{49} \mathrm{Ibdem}$, nota 47, p.32-35.

${ }^{50}$ LESSA, Guilherme Thofehrn. Irrecorribilidade das decisões interlocutórias e regime de agravo de no projeto do novo CPC. Revista dos Tribunais Online. p.2. Disponível em: >http://goo.gl/fLODZU $<$. Acesso em: 10/01/2015, p.7. 
Revista Eletrônica de Direito Processual - REDP. Volume 15. Janeiro a Junho de 2015 Periódico Semestral da Pós-Graduação Stricto Sensu em Direito Processual da UERJ. Patrono: José Carlos Barbosa Moreira. www.redp.com.br ISSN 1982-7636 PP 416-434 BUENO, Cassio Scarpinella. Curso sistematizado de direito processual civil, vol. 5: recursos, processos e incidentes nos tribunais, sucedâneos recursais: técnicas de controle das decisões jurisdicionais / - 5. ed. rev. e atual. - São Paulo: Saraiva, 2014. BUZAID, Alfredo. Exposição de motivos do código de processo civil. In Código de Processo Civil, HISTÓRICO DA LEI Vol. I TOMO I. Disponível em:>http://www2.senado.leg.br/bdsf/bitstream/handle/id/177828/CodProcCivil\%20197 4.pdf? sequence $=4<$ Acesso em: 10/01/2015.

CÂMARA, Alexandre Freitas. Lições de direito processual civil. $23^{\circ}$. ed. São Paulo: Atlas, 2014. v. 2.

CARVALHO, Milton Paulo de. Conselho Superior de Direito da Fecomercio. Relatório da comissão de estudo e parecer sobre o projeto de código de processo civil. p.58. Disponível em:> http://s.conjur.com.br/dl/reforma-cpc-relatorio-conselho-superior.pdf< Acesso em:10/01/2015.

DIDIER JR., Fredie. Curso de direito processual civil: introdução do direito processual civil e ao processo de conhecimento. $15^{\circ}$ ed. Salvador: JusPodivm, 2013, vol. 1.

DIDIER JR., Fredie, BRAGA, Paula Sarno e OLIVEIRA, Rafael. Curso de direito processual civil: teoria da prova, direito probatório, teoria do precedente, decisão judicial, coisa julgada e antecipação dos efeitos da tutela. $8^{\circ}$. ed. Salvador: JusPodivm, 2013, vol. 2.

DIDIER JR., Fredie, CUNHA, Leonardo da Carneiro da. Curso de direito processual civil: meios de impugnação às decisões judiciais e processos nos tribunais. $11^{\circ} \mathrm{ed}$. Salvador: JusPodivm, 2013, v.3.

GREZELLE, Vinicius. Comentários ao Projeto de Lei $\mathbf{n}^{\mathbf{0}}$. 8.046/2010, Proposta de um Novo Código de Processo Civil. Porto Alegre: EdiPUCRS, 2012.

JORGE, Flávio Cheim. A nova reforma processual. $2^{\circ}$ ed. São Paulo: Saraiva, 2003.

LESSA, Guilherme Thofehrn. Irrecorribilidade das decisões interlocutórias e regime de agravo de no projeto do novo CPC. Revista dos Tribunais Online. Disponível em: $>$ http://goo.gl/fLODZU<. Acesso em: 10/01/2015.

MACHADO, Antônio Cláudio da Costa. Reforma do CPC é vontade de criar totalitarismo judicial. Disponível em:> http://www.conjur.com.br/2013-mar-22/costamachado-reforma-cpc-vontade-criar-totalitarismo-judicial<. Acesso em: 10/01/2015. 
Revista Eletrônica de Direito Processual - REDP. Volume 15. Janeiro a Junho de 2015 Periódico Semestral da Pós-Graduação Stricto Sensu em Direito Processual da UERJ. Patrono: José Carlos Barbosa Moreira. www.redp.com.br ISSN 1982-7636 PP 416-434 MARCUSE, Herbert. Ideologia da sociedade industrial. 3. ed. Rio de Janeiro: Jorge Zahar, 1969

MARINONI, Luiz Guilherme. MITIDIERO, Daniel. O projeto do CPC: críticas e propostas. $1^{\circ} \mathrm{ed}, 2^{\circ}$ tiragem. São Paulo, Editora Revista dos Tribunais, 2010.

MOREIRA, José Carlos Barbosa. Item do pedido sobre o qual não houve decisão. Possibilidade de reiteração noutro processo. Temas de direito processual civil segunda série. $2^{\circ}$ ed. São Paulo: Saraiva, 1988.

MOREIRA, José Carlos Barbosa. Por um processo socialmente efetivo. RePro 105/184. São Paulo: Ed. RT, 2002.

NERY JUNIOR, Nelson; NERY, Rosa Maria de Andrade. Código de Processo Civil Comentado. Revista dos Tribunais, $13^{\circ}$ ed. São Paulo, 2013.

NEVES, Daniel Amorim Assumpção. Manual de direito processual civil - 6. ed. rev., atual. eampl. - Rio de Janeiro: Forense; São Paulo: Método, 2014.

NEVES, Marcelo. A constitucionalização simbólica. São Paulo: WMF Martins Fontes, 2007. (Coleção Justiça e Direito.).

REsp 1372802-RJ. Disponível em: >http://www.tjsp.jus.br/Download/SecaoDireitoPrivado/Boletins/GapriInformaAbril201 4.pdf $<$. Acesso em: 10/01/2015.

SANTOS, José Carlos Van Cleef de Almeida. O projeto do novo código de processo civil e a (re) afirmação da decisão interlocutória de mérito. Revista dos Tribunais Online. p.14. Disponível em: http://goo.gl/DO41Hc. Acesso em: 10/01/2015. 